\title{
Evaluation of the Methylation and Acetylation Profiles of Dinitroaniline Herbicides and Resveratrol on the V79 Cell Line
}

\section{Dinitroanilin Herbisitlerin ve Resveratrolün Metilasyon ve Asetilasyon Profillerinin V79 Hücre Hattında Değerlendirilmesi}

\author{
(1) Zehra SARIGÖL KILIÇ1, (1) Tuğbagül ÇAL2, (1) Ülkü ÜNDEĞER BUCURGAT2* \\ 1Ammon Analytical Laboratory, Linden, USA \\ 2Hacettepe University Faculty of Pharmacy, Department of Pharmaceutical Toxicology, Ankara, Turkey
}

\begin{abstract}
Objectives: Herbicides are among the most widely used pesticide compounds for plant growth control worldwide. Risk assessment of the dinitroaniline-derived herbicides pendimethalin and trifluralin is important for foodborne or other means of exposure. In this study, we aimed to evaluate the methylation and acetylation profiles of pendimethalin and trifluralin, which we have high levels of exposure to in various ways. Furthermore, we also determined the protective effect of resveratrol, an antioxidant compound, against the possible toxic effects of these pesticides. Materials and Methods: The effects of pendimethalin and trifluralin alone $(25,50,100 \mu \mathrm{M})$ and in combination with resveratrol $(100 \mu \mathrm{M})$ on DNA methyltransferase (DNMT1) 1, 3a, and 3b; and histone deacetylase (HDAC) 1 and HDAC3 gene expression were evaluated by real-time polymerase chain reaction.

Results: According to the results, pendimethalin caused a significant decrease in DNMT1, 3a, 3b and HDAC expressions at all concentrations, whereas $\mathrm{HDAC1}$ and 3 expression was increased at the concentration of $25 \mu \mathrm{M}$, when applied together with resveratrol. There were no changes in DNMT1 or 3b expression levels. Unlike pendimethalin, trifluralin increased DNMT1 expression in a concentration-dependent manner. While DNMT3a and DNMT3b expression levels increased significantly, HDAC1 and 3 expression levels did not change significantly. The expression levels of HDAC1 and HDAC3 increased at all concentrations of trifluralin combination with resveratrol. Moreover, DNMT levels increased at the concentrations of 50 and $100 \mu \mathrm{M}$.

Conclusion: Epigenetic gene expression results showed that pendimethalin and trifluralin might cause tissue function loss and chromosome damage as a result of direct effects on cell viability by causing expression level changes in all studied genes. It can also be concluded that the changes that occur in gene expression may induce tumor development. Further studies are needed to elucidate the possible toxicity mechanisms of these herbicides, considering the relationship between epigenetic changes and various diseases.
\end{abstract}

Key words: Pendimethalin, trifluralin, epigenetic, DNA methyltransferase, histone deacetylase

Öz

Amaç: Herbisitler, dünya genelinde bitki büyüme kontrolü için en yaygın kullanılan pestisit bileşiklerindendir. Dinitroanilin türevi herbisitlerden olan pendimetalin ve trifluralinin risk değerlendirmesinin yapılması, gıda kaynaklı veya diğer yollardan gerçekleşen maruziyetler açısından önemlidir. Bu çalışmada, çeşitli yollarla yüksek düzeylerde maruz kaldığımız pendimetalin ve trifluralinin metilasyon ve asetilasyon profillerini değerlendirmeyi amaçladık. Ayrıca, bir antioksidan bileșik olan resveratrolün, bu pestisitlerin olası toksik etkilerine karşı koruyucu etkisini belirledik.

Gereç ve Yöntemler: Pendimetalin ve trifluralinin tek başlarına $(25,50,100 \mu \mathrm{M})$ ve resveratrol $(100 \mu \mathrm{M})$ ile kombinasyon halinde DNA metiltransferaz (DNMT) 1, 3a, 3b; histon deasetilaz (HDAC) 1 ve HDAC3 gen ekspresyonları gerçek zamanlı polimeraz zincir reaksiyonu yöntemiyle değerlendirilmiştir. Bulgular: Sonuçlara göre pendimetalin tüm konsantrasyonlarda DNMT1, 3a, 3b ve HDAC ekspresyonlarında anlamlı ölçüde azalmaya neden olurken, resveratrol ile birlikte uygulandığında HDAC1 ve 3 ekspresyonları $25 \mu \mathrm{M}$ konsantrasyonunda artmıştır. DNMT1 ve $3 \mathrm{~b}$ ekspresyon düzeylerinde ise değişiklik olmamıştır. Pendimetalinin aksine, trifluarin DNMT1 ekspresyonunu konsantrasyonla bağımlı olarak artırmıştır. DNMT3a ve DNMT3b

This manuscript was presented at the $52^{\text {nd }}$ Congress of the European Societies of Toxicology (EUROTOX) Fibes Congress Center Seville, Spain, $4^{\text {th }} 7^{\text {th }}$ September 2016.

*Correspondence: E-mail: uundeger@hacettepe.edu.tr, Phone: +90 5353685391 ORCID-ID: orcid.org/0000-0002-6692-0366

Received: 11.09.2019, Accepted: 31.10.2019

Turk J Pharm Sci, Published by Galenos Publishing House. 
ekspresyon düzeylerinde de anlamlı artış gözlenirken, HDAC1 ve 3 düzeylerinde anlamlı değişiklik gözlenmemiştir. Trifluarinin resveratrol ile kombinasyonunda ise, HDAC1 ve HDAC3 ekspresyon düzeyleri tüm konsantrasyonlarda artış göstermiștir. Ayrıca, DNMT düzeyleri 50 ve 100 M konsantrasyonlarında artmıştır.

Sonuç: Epigenetik gen ekspresyonu sonuçları, pendimetalin ve trifluralinin çalışılan tüm genlerde ekspresyon düzeylerinde değişikliklere neden olarak hücre canlıı̆̆ı üzerindeki doğrudan etkilerinin bir sonucu ile doku fonksiyon kaybına ve kromozom hasarına neden olabilir. Ayrıca, gen ifadelerinde meydana gelen değişikliklerin tümör gelişimini indükleyebileceği sonucuna varılabilir. Epigenetik değişikliklerin çeșitli hastalıklarla ilişkisi düşünülerek bu herbisitlerin olası toksisite mekanizmalarının aydınlatılması için ileri çalışmalara ihtiyaç bulunmaktadır.

Anahtar kelimeler: Pendimetalin, trifluralin, epigenetik, DNA metiltransferaz, histon deasetilaz

\section{INTRODUCTION}

The most important problem for humans since the establishment of residential life has been to produce sufficient nutrients. For this purpose, it is necessary to eliminate insects, fungi, weeds, and other harmful organisms that damage crops in order to increase the quantity and quality of the product. It is also important to combat these pests in terms of health, given the fact that they spread diseases. Although the use of pesticides is necessary, toxic effects can be observed in organisms and in the environment as a result of widespread and uncontrolled use. Due to incorrect or careless use of pesticides, cases of mass poisoning can occur. In addition, long-term pesticide exposure is linked to cancer, immune system damage, and reproductive toxicity. ${ }^{2}$

Herbicides, which are among the most commonly used pesticide compounds in the world, are chemical compounds or cultured biological organisms controlling or suppressing plant growth. ${ }^{3}$ Pendimethalin and trifluralin are dinitroaniline herbicides that provide the control of certain broad-leaf and grassy weeds inhibiting mitosis. ${ }^{4-6}$ These herbicides have been used on vegetables, tobacco, oil seed, ornamentals, tomatoes, and cotton for a long time. ${ }^{4,5}$ For this reason, they can affect health via environmental pollution or diet. ${ }^{7}$

Pendimethalin and trifluralin synthesis can cause the formation of reactive compounds known as nitrosamines. Nitrosamines are alkylating agents and can cause DNA damage by formation of adducts. ${ }^{8}$ Additionally, epigenetic changes, which are basically related to DNA methylation and histone acetylation mechanisms, are as important as genetic changes because of the 1 genome/n epigenomes relation. The genome-epigenome relationship is thought to play an active role in basic biological functions such as cell viability, cell division, cell differentiation, and phenotypic changes. ${ }^{9}$ Although epigenetic research has focused on embryonic development, aging, and cancer, recent research has been advancing in various areas such as the immune system, cardiovascular system, neurodegenerative diseases, obesity, and diabetes. ${ }^{10,11}$

In the present study, the epigenetic potential of pendimethalin and trifluralin on Chinese hamster lung fibroblast (V79) cells were investigated. We evaluated the DNA methyltransferase (DNMT) 1, 3a, and 3b; and histone deacetylase (HDAC) 1 and 3 levels on V79 cells after $24 \mathrm{~h}$ treatment of pendimethalin and trifluralin at the concentrations of 25,50 , and $100 \mu \mathrm{M}$, which were determined based on our previous study results from a neutral red uptake assay and comet assay. ${ }^{12}$ The effects of resveratrol, a strong antioxidant compound, were also examined at the concentration of $100 \mu \mathrm{M}$.

\section{MATERIALS AND METHODS}

Pendimethalin, trifluralin, and resveratrol solution preparation Pendimethalin (98.8\% purity, CAS no: 40487-42-1), trifluralin (98.8\% purity, CAS no: 1582-09-8), and resveratrol (99\% purity, CAS no: R5010) were purchased from Sigma-Aldrich. Pendimethalin stock solution $(500 \mathrm{mM})$ was prepared in dimethyl sulfoxide (DMSO): olive oil (1:3, v/v), and trifluralin (500 $\mathrm{mM}$ ) and resveratrol stock solution $(0.5 \mathrm{mM})$ were prepared in phosphate buffered saline containing DMSO [final DMSO concentration was $1 \%(\mathrm{v} / \mathrm{v})]$.

\section{Cell culture}

V79 cells obtained from the American Type Culture Collection (ATCC; Rockville, MD, USA) were incubated in RPMI 1640 medium supplemented with $1 \%$ penicillin-streptomycin solution, $10 \%$ heat-inactivated fetal bovine serum (Lot: 094M3288), and $2 \mathrm{mM} \mathrm{L}$-glutamine at $37^{\circ} \mathrm{C}$ and in $5 \% \mathrm{CO}_{2}$ for $24 \mathrm{~h}$. After $24 \mathrm{~h}$, the cells were harvested and were transferred to 6 well plates as 30,000 cells $/ 2 \mathrm{~mL}$ medium of each. Pendimethalin and trifluralin solutions were added to the wells at the concentrations of 25 , 50 , and $100 \mu \mathrm{M}$ after $24 \mathrm{~h}$. Moreover, $100 \mu \mathrm{M}$ resveratrol was used as a single concentration and additionally added to the concentrations of pendimethalin and trifluralin. For the negative control, 1\% DMSO and 1\% DMSO/3\% olive oil were used. The cells were incubated for $24 \mathrm{~h}$ and harvested from the wells and centrifuged at $1000 \mathrm{rpm}$ for $5 \mathrm{~min}$.

\section{Evaluation of gene expression profiles by reverse transcription-} polymerase chain reaction (RT-PCR) assay

RNA isolation was performed according to the instructions of the RNeasy Mini Kit (QIAGEN). The cell suspensions were filtrated using a gDNA eliminator column after centrifugation. Then they were transferred to the RNeasy spin column and washed with the solutions as given in the kit procedure.

The measurement of the amount and quality of the eliminated RNA samples was performed by Maestrogen Nanodrop. Briefly, $1 \mu \mathrm{L}$ of the sample was loaded to the base portion fiber terminal. All the samples' OD 260/280 ratios were found in the range of 1.6-1.8.

For the purpose of synthesizing cDNA from the RNA samples, an $\mathrm{RT}^{2}$ First Strand Kit (QIAGEN) was used according to the instructions. The denaturation of the RNA samples was performed at $42^{\circ} \mathrm{C}$ for $5 \mathrm{~min}$ in the qRT-PCR device. To preserve linearity, the samples were placed on a cold surface. After that, reverse-transcription enzymes were added to the samples and the cDNA synthesis process was performed at $42^{\circ} \mathrm{C}$ for $15 \mathrm{~min}$ and $90^{\circ} \mathrm{C}$ for $5 \mathrm{~min}$. The synthesized cDNA samples were stored at $-20^{\circ} \mathrm{C}$. The PCR primers used are listed in Table 1. 
For measuring the expression levels of genes, cDNA samples were mixed with $\mathrm{RT}^{2}$ SYBR Green qPCR MasterMix and $\mathrm{RT}^{2}$ qPCR primers (DNMT1, DNMT3a, DNMT3b, HDAC1, HDAC3, and PPIA) and the expression performed with the qRT-PCR device under the conditions of hold at $95^{\circ} \mathrm{C} 15 \mathrm{~min}$ and cycle at $95^{\circ} \mathrm{C}$ $15 \mathrm{~s}$ and $60^{\circ} \mathrm{C} 30 \mathrm{~s}$, for 40 cycles. The results were recorded at $60^{\circ} \mathrm{C}$. The threshold limit was set to 0.05 and the cycle threshold (CT) values of the samples were calculated (Table 1).13,14

\section{Statistical analysis}

Statistics of the CT values were prepared using the onlinebased program $\mathrm{RT}^{2}$ profiler PCR Data Analysis 3.5. The $\triangle \triangle \mathrm{CT}$ method was used to interpret the gene expression data. ${ }^{15}$ When evaluating the results, the upper limit CT value was taken as 35 . Values higher than 35 were evaluated as 35 . All experiments were performed twice.

\section{RESULTS}

\section{Effects of trifluralin on gene expression}

According to the $\triangle \triangle C T$ values, DNMT1 expression in V79 cells increased at a higher level and concentration relative to the control group with $24 \mathrm{~h}$ incubation of trifluralin. The levels of DNMT3a and 3b only increased significantly at high concentration. There were no significant changes in HDAC1 or 3 levels.

When resveratrol was administered alone, the levels of DNMT1, $3 a$, and $3 b$; and HDAC1 increased significantly compared to the control, but HDAC3 levels remained unchanged.

Furthermore, when trifluralin and resveratrol were coadministered, HDAC1 and 3 expression levels were significantly increased at all concentrations. DNMT levels were increased in 25 and $50 \mu \mathrm{M}$ trifluralin and resveratrol, whereas $100 \mu \mathrm{M}$ trifluralin and resveratrol were low in expression.

Generally, when the results of fold regulation and biological significance of trifluralin and resveratrol were examined, a significant increase in expression was observed in all genes except HDAC3 when resveratrol was administered alone. It was observed that trifluralin generally decreased HDAC1 and 3 expression. When trifluralin was combined with resveratrol, it caused an increase in HDAC1 and 3 expression, except $100 \mu \mathrm{M}$ trifluralin and resveratrol administration. Additionally, DNMT1 showed a significant increase in all studied concentrations, whereas DNMT3a and 3b expression levels increased when $100 \mu \mathrm{M}$ trifluralin was given. DNMT3b decreased at all concentrations when co-administered with resveratrol, while DNMT3a was significantly reduced only when $25 \mu \mathrm{M}$ trifluralin and $100 \mu \mathrm{M}$ resveratrol were co-administered.

The $\triangle \mathrm{CT}, \Delta \triangle \mathrm{CT}$, fold change, and fold regulation values of the genes are given in Tables 2-5.

\section{Effects of pendimethalin on gene expression}

When $\triangle \triangle C T$ values were compared, it was observed that DNMT and HDAC expression levels were significantly decreased in all concentrations of pendimethalin. Moreover, DNMT1 and HDAC1 and 3 expression levels were increased significantly at only $25 \mu \mathrm{M}$ pendimethalin concentration when given together with resveratrol. However, all gene expression was significantly increased when resveratrol was administered alone.

When the pendimethalin and resveratrol fold-regulation and biological significance results were evaluated, it was seen that

\section{Table 1. Gene sequences of primers ${ }^{13,14}$}

\begin{tabular}{lll}
\hline Gene & Forward & Reverse \\
\hline DNMT1 & 5'-AAC CTT CAC CTA GCC CCA G-3' & 5'-CTC ATC CGA TTT GGC TCT TCA-3' \\
\hline DNMT3a & 5'-CGA CCC ATG CCA AGA CTC ACC TTC CAG-3' & 5'- CCT GGT GGA ATG CAC TGC AGA AGG A-3' \\
\hline DNMT3b & 5'-TAC ACA GAC GTG TCC AAC ATG GGC-3' & 5'-GGA TGC CTT CAG GAA TCA CAC CTC-3' \\
\hline HDAC1 & 5'-CTG TCC GGT ATT TGA TGG CT-3' & 5'-CAC GAA CTC CAC ACA CTT GG-3' \\
\hline HDAC3 & 5'-TCT GAG GAC TAC ATC GAC TCC-3' & 5'-GTC GCC ATC ATA GAA CTC AT TG-3' \\
\hline PPIA & 5'-ATG GTC AAC CCC ACC GTG T-3' & 5'-TCT GCT GTC TTT GGG ACC TTG TC-3'
\end{tabular}

DNMT: DNA methyltransferase, HDAC: Histone deacetylase, PPIA: Peptidylprolyl isomerase A

Table 2. $\triangle \mathrm{CT}$ values of trifluralin and resveratrol the values are expressed in mean \pm standard deviation format

\begin{tabular}{|c|c|c|c|c|c|c|c|c|}
\hline Gene & $\begin{array}{l}\text { Control (1\% } \\
\text { DMSO) }\end{array}$ & r 100 & $\mathrm{t} 25$ & $t 50$ & $t 100$ & $t 25+r 100$ & $t 50+r 100$ & $t 100+r 100$ \\
\hline PPIA & 0 & 0 & 0 & 0 & 0 & 0 & 0 & 0 \\
\hline DNMT1 & $11.29 \pm 2.55$ & $3.465 \pm 19.70$ & $6.755 \pm 0.346$ & $5.085 \pm 2.84$ & $4.67 \pm 0.226$ & $3.855 \pm 16.94$ & $2.07 \pm 14.07$ & $4.785 \pm 14.61$ \\
\hline DNMT3a & $5.68 \pm 13.94$ & $2.48 \pm 21.10$ & $6.754 \pm 0.347$ & $6.375 \pm 1.02$ & $4.68 \pm 0.225$ & $9.375 \pm 22.21$ & $6.4 \pm 17.90$ & $6.42 \pm 13.50$ \\
\hline DNMT3b & $7.3 \pm 14.96$ & $3.18 \pm 20.11$ & $6.756 \pm 0.344$ & $6.374 \pm 1.02$ & $4.65 \pm 0.224$ & $9.135 \pm 22.54$ & $9.66 \pm 18.76$ & $24.305 \pm 3.81$ \\
\hline HDAC1 & $5.275 \pm 13.88$ & $2.83 \pm 20.60$ & $6.753 \pm 0.347$ & $6.373 \pm 1.01$ & $4.68 \pm 0.227$ & (-) $3.93 \pm 5.99$ & $(-) 6.905 \pm 5.16$ & (-) $7.11 \pm 21.41$ \\
\hline HDAC3 & $2.54 \pm 8.71$ & $2.565 \pm 19.93$ & $6.755 \pm 0.345$ & $6.376 \pm 1.04$ & $4.69 \pm 0.223$ & (-) $6.36 \pm 1.61$ & (-) $7.875 \pm 0.86$ & (-) $6.115 \pm 3.58$ \\
\hline
\end{tabular}

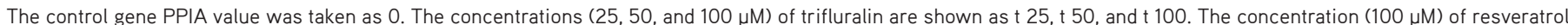
is shown as r 100), DNMT: DNA methyltransferase, HDAC: Histone deacetylase, PPIA: Peptidylprolyl isomerase A, DMSO: Dimethyl sulfoxide, CT: Cycle threshold 
Table 3. $\Delta \Delta \mathrm{CT}$ values of trifluralin and resveratrol the values are expressed as $\Delta \Delta \mathrm{CT}$ values

\begin{tabular}{lllllllll} 
Gene & Control (1\% DMSO) & $\mathrm{r} 100$ & $\mathrm{t} 25$ & $\mathrm{t} 50$ & $\mathrm{t} 100$ & $\mathrm{t} 25+\mathrm{r} 100$ & $\mathrm{t} 50+\mathrm{r} 100$ & $\mathrm{t} 100+\mathrm{r} 100$ \\
\hline PPIA & 1 & 1 & 1 & 1 & 1 & 1 & 1 & 1 \\
\hline DNMT1 & 0.000399 & 0.090559 & 0.009259 & 0.029462 & 0.039282 & 0.069108 & 0.238159 & 0.036272 \\
\hline DNMT3a & 0.019505 & 0.179244 & 0.009258 & 0.012049 & 0.039283 & 0.001506 & 0.011842 & 0.011679 \\
\hline DNMT3b & 0.006346 & 0.110338 & 0.009260 & 0.012048 & 0.039280 & 0.001779 & 0.001236 & 0 \\
\hline HDAC1 & 0.025827 & 0.140632 & 0.009257 & 0.012047 & 0.039283 & 15.242208 & 119.842848 & 70.007239 \\
\hline HDAC3 & 0.171943 & 0.168989 & 0.009259 & 0.012050 & 0.039284 & 82.139257 & 234.753035 & 69.310403 \\
\hline
\end{tabular}

The control gene PPIA value was taken as 1 . The concentrations $(25,50$, and $100 \mu \mathrm{M})$ of trifluralin are shown as $t 25$, $t 50$, and $t 100$. The concentration $(100 \mu M)$ of resveratrol is shown as r 100), DNMT: DNA methyltransferase, HDAC: Histone deacetylase, PPIA: Peptidylprolyl isomerase A, DMSO: Dimethyl sulfoxide, CT: Cycle threshold

\section{Table 4. The fold change values of trifluralin and resveratrol the control gene PPIA value was taken as 1}

\begin{tabular}{|c|c|c|c|c|c|c|c|}
\hline Gene & r 100 & $t 25$ & t 50 & $t 100$ & $t 25+r 100$ & $t 50+r 100$ & $t 100+r 100$ \\
\hline PPIA & 1 & 1 & 1 & 1 & 1 & 1 & 1 \\
\hline DNMT1 & $226.7565^{+}$ & $23.1831^{+}$ & $73.7719^{+}$ & $98.36^{+}$ & $173.0446^{+}$ & $596.343^{+}$ & $90.8239^{+}$ \\
\hline DNMT3b & $17.3878^{+}$ & 1.459 & 1.8987 & $6.1903^{+}$ & $0.2803^{*}$ & $0.1948 *$ & $0 *$ \\
\hline HDAC1 & $5.4453^{+}$ & $0.3585^{\star}$ & $0.4665^{\star}$ & 1.521 & $590.1754^{+}$ & $4640.2924^{+}$ & $380.2803^{+}$ \\
\hline
\end{tabular}

The concentrations $(25,50$, and $100 \mu \mathrm{M})$ of trifluralin are shown as $t 25, t 50$, and $t 100$. The concentration $(100 \mu \mathrm{M})$ of resveratrol is shown as $r 100$. A significant increase in gene expression is shown with +, a decrease in gene expression is shown with *. P $<0.05$ means significantly different from the negative control, DNMT: DNA methyltransferase, HDAC: Histone deacetylase, PPIA: Peptidylprolyl isomerase $A$

Table 5. The fold regulation values and biological significance of trifluralin and resveratrol the control gene PPIA value was taken as 1

\begin{tabular}{|c|c|c|c|c|c|c|c|}
\hline Gene & r 100 & $t 25$ & $t 50$ & $t 100$ & $t 25+r 100$ & $t 50+r 100$ & t $100+$ r 100 \\
\hline PPIA & 1 & 1 & 1 & 1 & 1 & 1 & 1 \\
\hline DNMT1 & $226.757^{+}$ & $23.1831^{+}$ & $73.7719^{+}$ & $98.36^{+}$ & $173.0446^{+}$ & $596.3436^{+}$ & $90.8239^{+}$ \\
\hline DNMT3b & $17.3878^{+}$ & 1.459 & 1.8987 & $6.1903^{+}$ & $-3.5677^{\star}$ & $-5.1337^{\star}$ & $-131527.049^{*}$ \\
\hline HDAC1 & $5.4453^{+}$ & $-2.7895^{\star}$ & $-2.1435^{\star}$ & 1.521 & $590.1754^{+}$ & $4640.2924^{+}$ & $-3.5677^{\star}$ \\
\hline
\end{tabular}

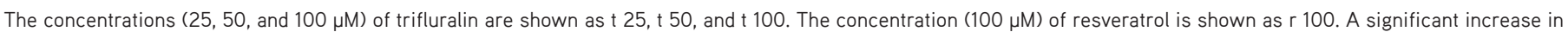

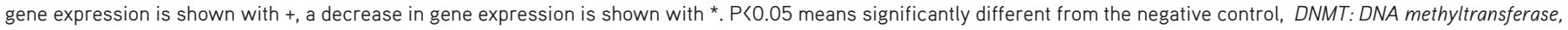
HDAC: Histone deacetylase, PPIA: Peptidylprolyl isomerase A

Table 6. $\triangle \mathrm{CT}$ values of pendimethalin and resveratrol the values are expressed in mean \pm standard deviation format

\begin{tabular}{lllllllll} 
Gene & $\begin{array}{l}\text { Control (1\% DMSO } \\
\% 3 \text { olive oil) }\end{array}$ & $\mathrm{p} \mathrm{25}$ & $\mathrm{p} 50$ & $\mathrm{p} 100$ & $\mathrm{p} 25+\mathrm{r} 100$ & $\mathrm{p} 50+\mathrm{r} 100$ & $\mathrm{p} 100+\mathrm{r} 100$ & $\mathrm{r} 100$ \\
\hline PPIA & 0 & 0 & 0 & 0 & 0 & 0 & 0 & 0 \\
\hline DNMT1 & $1.27 \pm 11.07$ & $8.88 \pm 2.12$ & $11.13 \pm 0.65$ & $7.58 \pm 0.52$ & $0.98 \pm 13.74$ & $6.98 \pm 0.12$ & $7.33 \pm 2.03$ & $(-) 10.47 \pm 0$ \\
\hline DNMT3a & $5.545 \pm 16.22$ & $10.28 \pm 0.14$ & $11.835 \pm 0.34$ & $13.33 \pm 0.41$ & $18.09 \pm 2.39$ & $14.86 \pm 0.18$ & $12.58 \pm 1.86$ & $2.11 \pm 20.57$ \\
\hline DNMT3b & $5.36 \pm 18.69$ & $10.215 \pm 0.049$ & $11.836 \pm 0.33$ & $13.32 \pm 0.40$ & $5.43 \pm 21.75$ & $15.025 \pm 0.049$ & $15.215 \pm 0.64$ & $2.81 \pm 19.58$ \\
\hline HDAC1 & $2.405 \pm 15.37$ & $10.27 \pm 0.13$ & $11.834 \pm 0.34$ & $13.34 \pm 0.41$ & $(-) 8.165 \pm 2.05$ & $13.83 \pm 1.06$ & $14.26 \pm 0.70$ & $(-) 11.74 \pm 0$ \\
\hline HDAC3 & $8.485 \pm 0.34$ & $9.53 \pm 0.91$ & $11.02 \pm 0.80$ & $10.765 \pm 1.05$ & $(-) 0.545 \pm 11.32$ & $9.175 \pm 0.17$ & $8.395 \pm 1.09$ & $2.21 \pm 20.43$
\end{tabular}

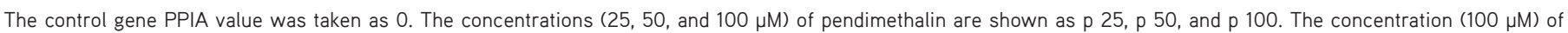
resveratrol is shown as r 100, DMSO: Dimethyl sulfoxide, DNMT: DNA methyltransferase, HDAC: Histone deacetylase, PPIA: Peptidylprolyl isomerase A, CT: Cycle theshold

pendimethalin caused a significant decrease in expression of all genes in all concentrations, whereas resveratrol increased expression in all genes when administered alone.
Additionally, when the biological significance of pendimethalin and resveratrol co-administered concentrations was evaluated, HDAC1 and 3 expression levels were increased with the effect 
of resveratrol at a concentration of $25 \mu \mathrm{M}$ of pendimethalin, but DNMT3a levels were significantly decreased. There were no changes in DNMT1 or 3b or HDAC3 levels, while expression of other genes was significantly reduced when $50 \mu \mathrm{M}$ pendimethalin and $100 \mu \mathrm{M}$ resveratrol were co-administered.

The $\Delta C T, \Delta \triangle C T$, fold change, and fold regulation values of the genes are given in Tables 6-9.

\section{DISCUSSION}

Although genetic material, which is the source of information and life of organisms, is very well protected against degradation by various mechanisms, it may be damaged by exposure to many factors, both internal and external. The DNA repair mechanisms are very active, but they are not sufficient or are repressed in some cases. These types of damage have temporary or permanent effects and may cause minor or major dysfunctions and diseases in the organism and affect future generations besides the organism first affected.

Within the scope of the present study, the possible epigenetic effects of pendimethalin and trifluralin, herbicide compounds that we are frequently exposed to in this country as well as the rest of the world, were investigated in the V79 cell line. It has been evaluated whether resveratrol, an antioxidant substance, has a protective effect on possible methylation and acetylation profile changes of these herbicides.

DNMT and HDAC expression levels were examined to investigate the effects of pendimethalin and trifluralin, dinitroaniline herbicide compounds whose genotoxicity potentials were determined, ${ }^{12}$ on epigenetic changes. Based on the genotoxicity Table 7. $\Delta \Delta C T$ values of pendimethalin and resveratrol the values are expressed as $\Delta \Delta C T$ values

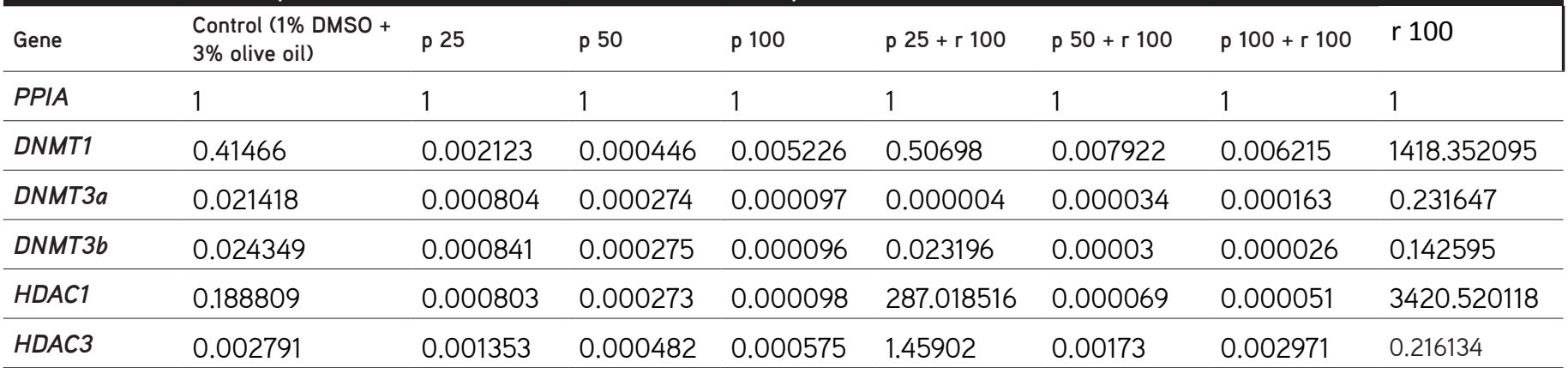

The control gene PPIA value was taken as 1 . The concentrations $(25,50$, and $100 \mu \mathrm{M})$ of pendimethalin are shown as $\mathrm{p} 25$, $\mathrm{p} 50$, and $\mathrm{p} 100$. The concentration $(100 \mu \mathrm{M})$ of resveratrol is shown as r 100), DNMT: DNA methyltransferase, HDAC: Histone deacetylase, PPIA: Peptidylprolyl isomerase A, CT: Cycle threshold, DMSO: Dimethyl sulfoxid

Table 8. The fold change values of pendimethalin and resveratrol the control gene PPIA value was taken as 1

\begin{tabular}{|c|c|c|c|c|c|c|c|}
\hline Gene & p 25 & p 50 & p 100 & p $25+r 100$ & p $50+$ r 100 & p $100+$ r 100 & r 100 \\
\hline PPIA & 1 & 1 & 1 & 1 & 1 & 1 & 1 \\
\hline DNMT1 & $0.0051^{*}$ & $0.0011^{\star}$ & $0.0126^{\star}$ & 1.2226 & $0.0191^{*}$ & $0.015^{\star}$ & $3420.52^{+}$ \\
\hline DNMT3b & $0.0346^{*}$ & $0.0112^{*}$ & $0.004^{*}$ & 0.9526 & $0.0012^{*}$ & $0.0011^{*}$ & $5.8563^{+}$ \\
\hline HDAC1 & $0.0043^{*}$ & $0.0014^{*}$ & $0.000 *$ & $1520.1521^{+}$ & $0.0004^{\star}$ & $0.0003^{*}$ & $18116.3^{+}$ \\
\hline
\end{tabular}

The concentrations $(25,50$, and $100 \mu \mathrm{M})$ of pendimethalin are showed as $\mathrm{p} 25, \mathrm{p} 50$, and p 100. The concentration $(100 \mu \mathrm{M})$ of resveratrol is shown as $r 100$. A significant increase in gene expression is shown with +, a decrease in gene expression is shown with * ${ }^{\text {. P }}<0.05$ means significantly different from the negative control, DNMT: DNA methyltransferase, HDAC: Histone deacetylase, PPIA: Peptidylprolyl isomerase A

Table 9. The fold regulation values and biological significance of pendimethalin and resveratrol the control gene PPIA value was taken as 1

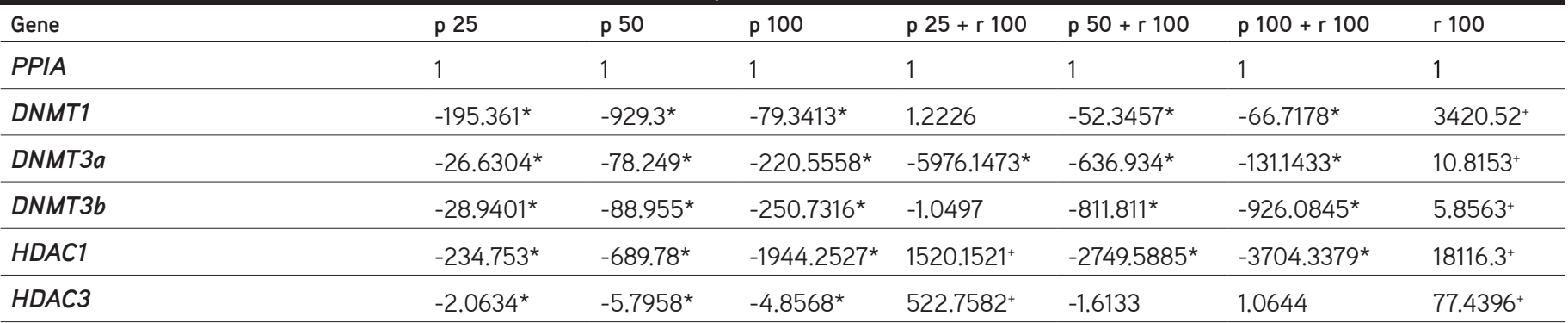

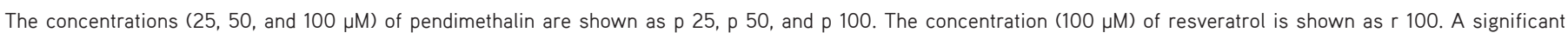

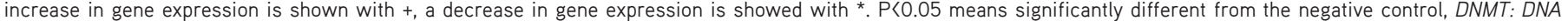
methyltransferase, HDAC: Histone deacetylase, PPIA: Peptidylprolyl isomerase A 
results, pendimethalin and trifluralin concentrations of 25,50 , and $100 \mu \mathrm{M}$ were selected for study.

While pendimethalin caused a significant decrease in DNMT levels, trifluralin increased DNMT1 expression and increased all of the DNMT genes at a concentration of $100 \mu \mathrm{M}$, causing a decrease in all other genes. Embryo death was observed in mice with increased methylation in DNMT1 gene disorder. Changes in DNMT1 expression lead to $X$ chromosome inactivation and imprinting loss. ${ }^{16}$ Disorders in DNMT1 gene expression cause proliferation disorders and mitotic defects leading to cell death. These effects in human colorectal cancer cells have been clearly observed. ${ }^{17}$ Similarly, it was reported that mouse fibroblast cells with DNMT1 defect were dragged into apoptosis via the $p-53$ pathway after several cell divisions, ${ }^{18}$ and apoptosis was observed as a result of a decrease in DNMT1 expression in germ cells. ${ }^{19}$ Studies have shown that the DNMT1 gene plays a critical role in cell proliferation and viability. In addition, DNMT1 function loss was directly associated with tumor formation, demonstrating tumor growth and chromosome instability in DNMT1-deficient mice. 20,21

Similar to DNMT1, DNMT3a and 3b have also been reported to play a critical role in embryonic development in mice. It was observed that mouse embryos with DNMT3b deficiency died at 9.5 embryonic days and multiple developmental defects occurred; pups without DNMT3a deficiency did not develop and died shortly after birth. ${ }^{22}$ Mutations in the DNMT3b gene in humans are the cause of a rare autosomal disease, immunodeficiency, centromere instability, and facial abnormalities syndrome. ${ }^{23}$ Furthermore, mutations in the DNMT3b gene cause a decrease in DNA methylation specific to pericentromeric regions on chromosomes 1,9 , and 16 , leading to chromosomal structure and function disorders. ${ }^{24}$

CpG methylation levels were found to be increased in lung cancer patients on two genes, SFTPA1 and SFTPA2, which encode surfactant protein $A$, associated with lung homeostasis and immunity. ${ }^{25}$ In another study, when epigenetic changes were examined in 28 nonsmoking lung adenocarcinoma patients, it was found that methylation levels decreased in tumor tissues compared to neighboring nonmalignant tissues and methylation increased in tumor tissues in CpG islands. ${ }^{26}$ Those findings were consistent with the results we obtained, and pendimethalin and trifluralin compounds significantly changed methylation levels.

Our evaluation of HDAC gene expression levels showed that both herbicidal compounds cause significant decrease in HDAC1 and 3 levels. HDAC1 and 3 consist of 93\% structurally the same proteins and belong to the class I histone deacetylases group. ${ }^{27,28}$ These genes are related to cell cycle control, cell survival, and differentiation. For this reason, the use of HDAC inhibitors for the treatment of cancer as an antineoplastic drug is contemplated. ${ }^{29,30}$ In a study of non-small lung cancer cells, it was observed that HDAC levels were increased in cancer cells and it was possible to fight cancer cells using HDAC inhibitors. ${ }^{31}$ However, these results are not consistent with our previous study, which was about the effects of pendimethalin and trifluralin on apoptosis and anti-apoptosis genes (p53, bax, bcl-2, casp3, casp9, and birc). According to our results, trifluralin downregulated the expression of all genes (1-500 $\mu \mathrm{M})$, but pendimethalin upregulated bcl-2 (100 and $500 \mu \mathrm{g} / \mathrm{mL}$ ) and birc5 $(500 \mu \mathrm{g} / \mathrm{mL})$ gene expression and had more effects on anti-apopitosis than trifluralin. ${ }^{32}$ These differences in results confirm that in order to reduce the possible carcinogenic effects of pendimethalin and trifluralin in humans, the permissible values and residual limits on foods should not be exceeded.

When the change in the epigenetic expression levels due to resveratrol was examined, the capacity of resveratrol supplementation to reverse the expression changes caused by the herbicides studied was limited. Additionally, normal gene expression levels were not achieved despite resveratrol, especially in HDAC genes. Furthermore, administration of resveratrol alone led to undesirable increases in gene expression possibly as a result of the pro-oxidant effect of resveratrol. ${ }^{33}$

\section{CONCLUSION}

Methylation and deacetylation gene expression are among the main pathways of epigenetic changes and they are the main causes of embryonic development disorders and chronic diseases.

According to the epigenetic gene expression results, pendimethalin and trifluralin may cause tissue function loss and chromosome damage as a result of direct effects on cell viability by causing expression level changes in all studied genes. Since the groups of cells we studied were healthy lung fibroblast cells, it can be concluded that the changes that occur in gene expression may induce tumor development. Considering the concentrations used, the genotoxic effects appear to be high. However, both herbicidal compounds we investigated are considered group $\mathrm{C}$, as a possible human carcinogen by the Environmental Protection Agency.

In addition to the beneficial effects of antioxidants such as resveratrol against oxidative DNA damage, there is also the risk of causing damage by pro-oxidant effects. Therefore, the use of dinitroaniline herbicides with high genotoxicity and epigenotoxicity potentials should be considered carefully and all the effects of antioxidant compounds should be examined in more detail.

\section{ACKNOWLEDGEMENTS}

This study was supported by Hacettepe University Scientific Research Projects Coordination Unit under Grant number THD2015-5535 and by the Scientific and Technological Research Council of Turkey under Grant number 1135049.

Conflicts of interest: No conflict of interest was declared by the authors. The authors alone are responsible for the content and writing of the paper. 


\section{REFERENCES}

1. Gupta P. Pesticide exposure-Indian scene. Toxicology. 2004;198:83-90.

2. Van Der Hoek W, Konradsen F, Athukorala K, Wanigadewa T. Pesticide poisoning: a major health problem in Sri Lanka. Soc Sci Med. 1998;46:495-504.

3. Grube A, Donaldson D, Kiely T, Wu L. Pesticides industry sales and usage - 2006 and 2007 Market Estimates. US EPA, Washington; 2011;15.

4. Grover R, Wolt JD, Cessna AJ, Schiefer HB. Environmental fate of trifluralin. Rev Environ Contam Toxicol. 1997;153:1-64.

5. Vighi M, Matthies M, Solomon KR. Critical assessment of pendimethalin in terms of persistence, bioaccumulation, toxicity, and potential for long-range transport. J Toxicol Environ Health B Crit Rev. 2017;20:1-21.

6. Hoffman J, Vaughn K. Mitotic disrupter herbicides act by a single mechanism but vary in efficacy. Protoplasma. 1994;179:16-25.

7. Wallace DR. Trifluralin. In: Wexler P, ed. Encyclopedia of Toxicology ( $3^{\text {rd }}$ ed). London; Academic Press; 2014:846-848.

8. Montesano R, Hall J. Nitrosamine Metabolism and Carcinogenesis. In: Chu EHY, Generoso WM, eds. Mutation, Cancer, and Malformation. Environmental Science Research, vol 31. Boston; Springer; 1984:447464.

9. Jiménez-Chillarón JC, Díaz R, Martínez D, Pentinat T, Ramón-Krauel M, Ribó S, Plösch T. The role of nutrition on epigenetic modifications and their implications on health. Biochimie. 2012;94:2242-2263.

10. Choi S-W, Friso S. Epigenetics: a new bridge between nutrition and health. Adv Nutr. 2010;1:8-16.

11. Niculescu MD. Nutritional epigenetics. ILAR Journal. 2012;53:270-278.

12. Sarıgöl Kılıç Z, Aydın S, Bucurgat Ündeğer Ü, Başaran N. In vitro genotoxicity assessment of dinitroaniline herbicides pendimethalin and trifluralin. Food Chem Toxicol. 2018;113:90-98.

13. Feng J, Zhou Y, Campbell SL, Le T, Li E, Sweatt JD, Silva AJ, Fan G. Dnmt1 and Dnmt3a maintain DNA methylation and regulate synaptic function in adult forebrain neurons. Nat Neurosci. 2010;13:423.

14. Chen S, Bellew C, Yao X, Stefkova J, Dipp S, Saifudeen Z, Bachvarov D, El-Dahr S. Histone deacetylase (HDAC) activity is critical for embryonic kidney gene expression, growth, and differentiation. J Biol Chem. 2011;286:32775-32789.

15. Livak KJ, Schmittgen TD. Analysis of relative gene expression data using real-time quantitative PCR and the 2- $\triangle \mathrm{CT}$ method. Methods. 2001;25:402-408

16. Sado T, Fenner MH, Tan SS, Tam P, Shioda T, Li E. X inactivation in the mouse embryo deficient for Dnmt1: distinct effect of hypomethylation on imprinted and random X inactivation. Dev Biol. 2000;225:294-303.

17. Chen T, Hevi S, Gay F, Tsujimoto N, He T, Zhang B, Ueda Y, Li E. Complete inactivation of DNMT1 leads to mitotic catastrophe in human cancer cells. Nat Genet. 2007;39:391.

18. Jackson-Grusby L, Beard C, Possemato R, Tudor M, Fambrough D, Csankovszki G, Dausman J, Lee P, Wilson C, Lander E, Jaenisch R. Loss of genomic methylation causes p53-dependent apoptosis and epigenetic deregulation. Nat Genet. 2001;27:31.
19. Takashima S, Takehashi M, Lee J, Chuma S, Okano M, Hata K, Suetake I, Nakatsuji N, Miyoshi H, Tajima S, Tanaka Y, Toyokuni S, Sasaki H, Kanatsu-Shinohara M, Shinohara T. Abnormal DNA methyltransferase expression in mouse germline stem cells results in spermatogenic defects. Biol Reprod. 2009;81:155-164.

20. Gaudet F, Hodgson JG, Eden A, Jackson-Grusby L, Dausman J, Gray JW, Leonhardt $H$, Jaenisch R. Induction of tumors in mice by genomic hypomethylation. Science. 2003;300:489-492.

21. Eden A, Gaudet F, Waghmare A, Jaenisch R. Chromosomal instability and tumors promoted by DNA hypomethylation. Science. 2003;300:455455.

22. Okano M, Bell DW, Haber DA, Li E. DNA methyltransferases Dnmt3a and Dnmt3b are essential for de novo methylation and mammalian development. Cell. 1999;99:247-257.

23. Hansen RS, Wijmenga C, Luo P, Stanek AM, Canfield TK, Weemaes CM, Gartler SM. The DNMT3B DNA methyltransferase gene is mutated in the ICF immunodeficiency syndrome. Proc Natl Acad Sci USA. 1999;96:14412-14417.

24. Xu GL, Bestor TH, Bourc'his D, Hsieh CL, Tommerup N, Bugge M, Hulten M, Qu X, Russo JJ, Viegas-Péquignot E. Chromosome instability and immunodeficiency syndrome caused by mutations in a DNA methyltransferase gene. Nature. 1999;402:187.

25. Grageda M, Silveyra P, Thomas NJ, DiAngelo SL, Floros J. DNA methylation profile and expression of surfactant protein $A 2$ gene in lung cancer. Exp Lung Res. 2015;41:93-102.

26. Mansfield AS, Wang L, Cunningham JM, Jen J, Kolbert CP, Sun Z, Yang P. DNA methylation and RNA expression profiles in lung adenocarcinomas of never-smokers. Cancer Genet. 2015;208:253-260.

27. De Ruijter AJ, Van Gennip AH, Caron HN, Stephan K, Van Kuilenburg AB. Histone deacetylases (HDACs): characterization of the classical HDAC family. Biochem J. 2003;370:737-749.

28. Strahl BD, Allis CD. The language of covalent histone modifications. Nature. 2000;403:41.

29. Gallinari P, Di Marco S, Jones P, Pallaoro M, Steinkühler C. HDACs, histone deacetylation and gene transcription: from molecular biology to cancer therapeutics. Cell Res. 2007;17:195.

30. Dokmanovic M, Clarke C, Marks PA. Histone deacetylase inhibitors: overview and perspectives. Mol Cancer Res. 2007;5:981-989.

31. Chun SM, Lee JY, Choi J, Lee JH, Hwang JJ, Kim CS, Suh YA, Jang SJ. Epigenetic modulation with HDAC inhibitor CG200745 induces anti-proliferation in non-small cell lung cancer cells. PloS one. 2015;10:e0119379.

32. Sarıgöl Kılıç Z, Ündeğer Bucurgat Ü. The apoptotic and anti-apoptotic effects of pendimethalin and trifluralin on A549 cells in vitro. Turk J Pharm Sci. 2018;15:364-369.

33. De La Lastra CA, Villegas I. Resveratrol as an antioxidant and prooxidant agent: mechanisms and clinical implications. Biochem Soc Trans. 2007;35:1156-1160. 